\title{
Distance-independent tree basal area growth models for Norway spruce, Douglas-fir and Japanese larch in Southern Belgium
}

\author{
Jérôme Perin $^{1}$ (D) Hugues Claessens ${ }^{1} \cdot$ Philippe Lejeune $^{1} \cdot$ Yves Brostaux $^{2} \cdot$ \\ Jacques Hébert ${ }^{1}$
}

Received: 4 August 2016/Revised: 21 November 2016/ Accepted: 30 November 2016

(C) Springer-Verlag Berlin Heidelberg 2016

\begin{abstract}
This paper presents new harmonized distanceindependent individual tree basal area growth models for Norway spruce, Douglas-fir and Japanese larch in pure even-aged stands in Southern Belgium. The selected model was originally developed for Norway spruce and Douglasfir in neighboring France. New formulations are proposed for some of the model components in order to lower the number of fitted parameters and facilitate the fitting procedure. The resulting models integrate the most recent corresponding top-height growth models and use four simple and usually collected explanatory variables: stand age, top-height, total basal area and tree girth at breast height. The modified formulations maintain similar fitting performances and make it easier to interpret the influence of the explanatory variables on tree growth. Parameters estimates were fitted on thousands of growth measurements gathered from several monitoring plots, forest management inventories and silvicultural field experiments that represent the wide range of site conditions and of forest management scenarios applied to coniferous stands in Southern Belgium. Cross-validation of the models revealed no bias and highlighted their consistent behavior over the entire
\end{abstract}

Communicated by Aaron R. Weiskittel.

Jérôme Perin

j.perin@ulg.ac.be

1 Forest Resources Management (GRF), Department of Biosystems Engineering (BIOSE), Gembloux Agro-Bio Tech (GxABT), University of Liege (ULG), 2 Passage des Déportés, 5030 Gembloux, Belgium

2 Applied Statistics, Computer Science and Mathematics (SIMa), Gembloux Agro-Bio Tech (GxABT), University of Liege (ULG), 2 Passage des Déportés, 5030 Gembloux, Belgium range of girth at breast height, age, top-height, site index and density represented in our dataset. Combining utility and robust performances, these models represent useful forest management tools, purposely ideal for forest simulation software development. Moreover, the flexibility and generic capabilities of the model formulation should make it easily adjustable for other species in even-aged stands.

Keywords Tree growth modeling - Softwood - Belgium . Picea abies · Pseudotsuga menziesii · Larix kaempferi

\section{Introduction}

Forest growth and yield modeling are used to analyze and estimate the key relationship linking forest stand development to various factors such as species composition, site characteristics and silvicultural management. There are various modeling approaches which are often classified into two main groups: mechanistic or process-based models which are based on presumed or observed mechanism and attempt to explain the eco-physiological processes of forest growth (Bossel 1991; Twery 2004), and empirical models which are based on measured data and describe the relation linking several stands or tree characteristics.

Empirical growth and yield models are commonly used in forestry to predict forest growth and production (Johnsen et al. 2001) and to compare the likely effects of various management scenarios on the evolution of forest resources (Peng 2000; Courbaud et al. 2001; Burkhart and Tomé 2012). Successful practical applications of such models range from simple growth and yield curves to more advanced forest management simulation software. Yield tables are probably the oldest and best known models used in forestry science and forest management (Pretzsch 2009). 
Early yield tables were based on inventory data and were not able to reflect the effects of changing management practices and environmental conditions and are therefore no longer valid in many cases (Pretzsch 2009; Pretzsch et al. 2014). Modern variable density yield tables and stand density management diagrams rely increasingly on growth and yield modeling to estimate the effect of variable management practices and environmental conditions on stand evolution (e.g., Longchang et al. 1991; Valbuena et al. 2008; Vacchiano et al. 2013).

The ever-increasing use of computer technology has made it easier to use more complex growth model to improve the resolution scale and to take more explanatory variables into account. Therefore, whole-stand modeling approaches are now considered outdated and individual tree-level modeling is the new standard (Weiskittel et al. 2011). These models are labeled distance-independent or distance-dependent depending on whether or not they include spatially explicit explanatory variables. Distancedependent models are very useful for research purpose: They have a high potential for estimating the impact of silvicultural treatment on individual tree growth and are well suited for both homogenous and heterogeneous stands structure and composition (e.g., Courbaud et al. 2001; Porté and Bartelink 2002; Pretzsch et al. 2002). However, distance-independent models are generally simpler and are considered as more practically oriented (e.g., Monserud and Sterba 1996; Andreassen and Tomter 2003; Deleuze et al. 2004), and their performances are known to generally only be slightly lower than distance-dependent ones in even-aged pure stands (e.g., Vanclay 1994; Wimberly and Bare 1996; Contreras et al. 2011).

Taking advantage of tree-level modeling, traditional yield tables are progressively replaced by the simulation software of silvicultural treatment (e.g., Pain 1997; Pretzsch et al. 2002; Pauwels et al. 2007; Dufour-Kowalski et al. 2012) that allows simulation of customized silvicultural management scenario at the tree level to accurately estimate growth and production based on the forester preferences. However, it is difficult, if not impossible, to ensure that the validity limits of the models introduced in the simulation software are always respected. Consequently, growth models should be designed with a greater focus on their structure to ensure that they exhibit a relevant behavior not only inside, but also outside of their validity area (Deleuze et al. 2004).

Although not native to Western Europe, Norway spruce (Picea abies (L.) Karst) is the most important timber production species in Southern Belgium (Alderweireld et al. 2015), where it is estimated that pure spruce stands account for about $30 \%$ of the productive forest area $(\approx 140,000$ ha) and approximately $40 \%$ of the standing timber volume $\left(\approx 46\right.$ million $\left.\mathrm{m}^{3}\right)$. However, for a variety of historical, socioeconomic and ecological reasons (Claessens 2001), the area devoted to this species declined steadily since the early 1990s partly in favor of other softwood species such as Douglas-fir (Pseudotsuga menziesii (Mirb.) Franco) and Japanese larch (Larix kaempferi (Lam.) Carrière). These two species were brought in Belgium over one century ago (Crahay 1900; Millard 1949), but large-scale plantations only started after the middle of the twentieth century (Claessens et al. 1996, 2002). Their higher growth rate and the technological quality of their wood make them interesting alternatives to Norway spruce.

In Southern Belgium, the first yield tables and site index curves fort these species were built by Dagnelie et al. (1988) for Norway spruce, by Rondeux et al. (1991) and Thibaut et al. (1995) for Douglas-fir and by Pauwels et al. (2007) for larch. More recently, differences were observed in Norway spruce and Douglas-fir stands between the field data and the values estimated using these tools, especially in stands aged 50 and over where the growth rate and the level of production were significantly underestimated (Perin et al. 2013). Therefore, the development of new growth and yield models was required to update the existing site index curves and yield tables.

In this context, we began the development of new harmonized growth and yield models that will be integrated in a simulation software to provide accurate tools for comparison and growth simulations in even-aged stands of Norway spruce, Douglas-fir, and larch. New harmonized top-height growth and site index models (Perin et al. 2013, 2014) constituted the first step, the next being harmonized girth increment models which are presented thereafter. Our forest simulation software will primarily be used to estimate the effect of various thinning regimes on individual tree growth and stand structure and to predict the evolution of existing stands using actual forest inventory data. As a result, we require growth models that offer good predictive performance while only using simple explanatory variables usually collected in forest inventory. We thus favor a tree-level distance-independent empiric modeling approach.

\section{Material}

The study concerns the Southern Belgium, especially at the south of the river Meuse where most of the softwood resource is located. The area is characterized by a subatlantic climate with an annual rainfall of $900-1300 \mathrm{~mm}$, well distributed along the year, and a mean annual temperature from 7.7 to $9.6{ }^{\circ} \mathrm{C}$. Coniferous stands cover a wide range of sites, but are most commonly planted on welldrained oligotrophic brown soils, except for spruce that is also planted on more humid soils. All the sampled plots 


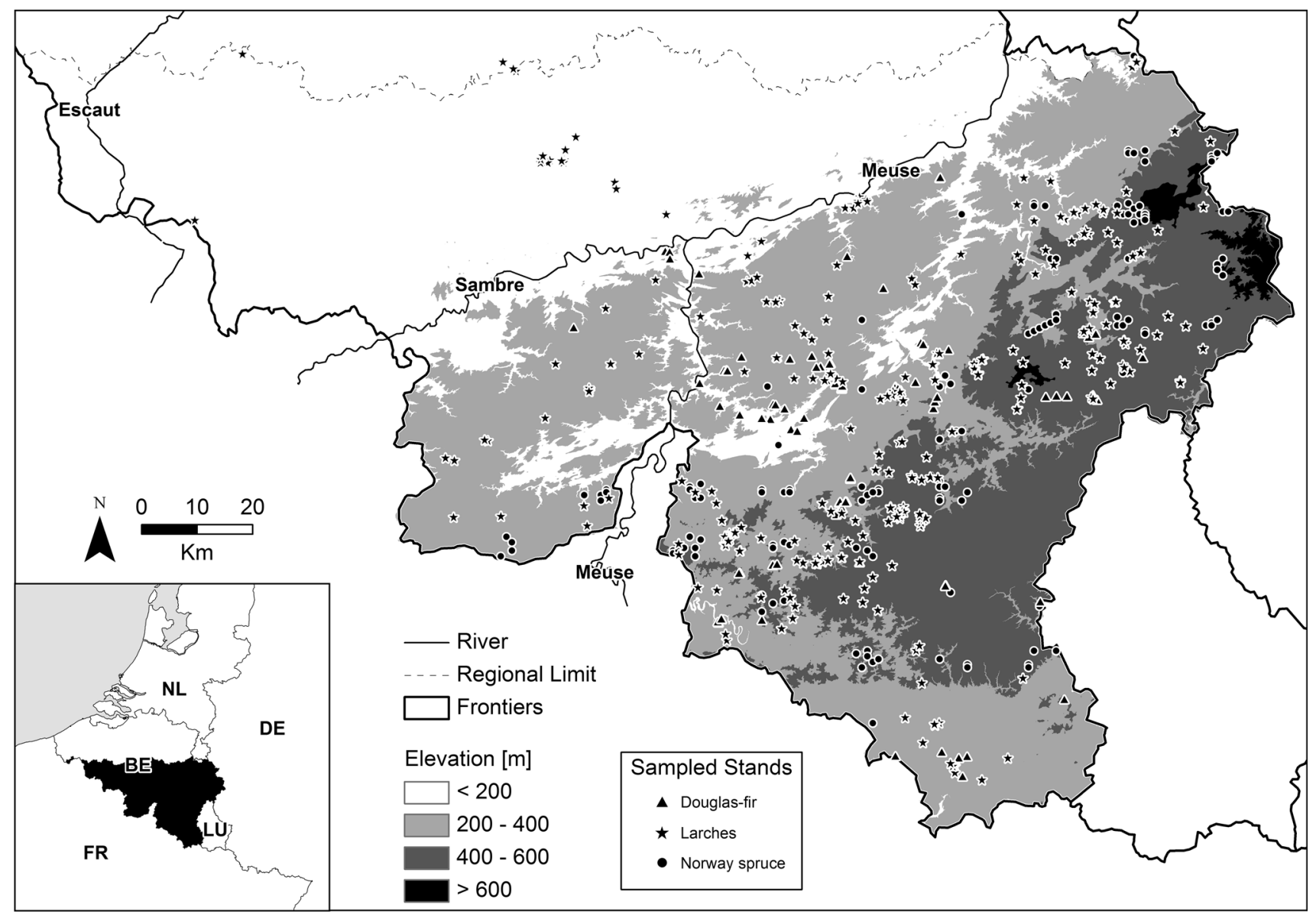

Fig. 1 Repartition of the sampled stands in the study area. Norway spruce stands are represented by round dots, Douglas-fir by triangular dots and larch by star dots

(Fig. 1) are located in even-aged and pure stands (Norway spruce, Douglas-fir or larch account for more than $90 \%$ of the stand basal area). The past silvicultural treatments applied to sampled stands are not always known, but coniferous silviculture in Belgium is widely based on evenaged stands established by planting high density (1500-3000 stems/ha) of 3- to 4-year-old planting stocks (Alderweireld et al. 2015). Coniferous stands are normally thinned every 5-10 years after reaching $13-20 \mathrm{~m}$ of dominant height, and unthinned stands are known to be fairly uncommon in Southern Belgium. Clearcutting is then usually applied shortly after those stands reach a top-height of, respectively, $30 \mathrm{~m}$ for Norway spruce and larch stands and $40 \mathrm{~m}$ for Douglas-fir.

Thousands of growth measurements were gathered from several monitoring plots, forest management inventories and silvicultural field experiments in pure even-aged stands of Norway spruce, Douglas-fir or larch. This includes several silvicultural field experiments installed during the 1970s in Norway spruce stands and monitored for close to three decades (Hébert et al. 2002) and an extensive plot network installed and monitored during the 1990s in larch stands (Pauwels et al. 2007). As a result, the sampled plots' design is rather heterogeneous: round and rectangular plot shapes, sizes ranging from 50 to 2400 square meters and monitoring durations varying from 3 to 27 years. We then selected all individual tree girth growth segments of 3-6 years measured over bark in stands of known age where top-height (Hdom), density (Nha) and total basal area (Gha) were measured. Following data quality control, the recovered dataset is composed of 51,159 growth segments measured on 18,135 trees in 537 plots monitored between 1979 and 2013. Norway spruce accounts for 33,931 of these data ( 7220 trees in 181 plots), larch for 14,382 (8988 trees in 289 plots) and Douglas-fir for 2846 (1927 trees in 67 plots).

These data represent all site conditions and the wide range of forest management scenarios applied to even-aged Norway spruce, Douglas-fir and larch stands of Southern Belgium, as well as more unusual silvicultural management scenario tested in several silvicultural field experiments (Table 1). Site index (SI, top-height at 50 years since 
Table 1 Main attributes of the selected permanent sample plots installed in even-aged pure stands of Norway spruce (181), Douglas-fir (67) and larch (289)

\begin{tabular}{|c|c|c|c|c|c|c|c|c|c|c|c|c|}
\hline & \multicolumn{4}{|c|}{ Norway spruce (Picea abies) } & \multicolumn{4}{|c|}{ Douglas-fir (Pseudotsuga menziesii) } & \multicolumn{4}{|c|}{ Larch (Larix kaempferi) } \\
\hline & Min & Mean & Max & SD & Min & Mean & Max & SD & Min & Mean & Max & SD \\
\hline Area $\left(\mathrm{m}^{2}\right)$ & 50 & 448 & 707 & 128 & 200 & 585 & 1500 & 346 & 100 & 626 & 2400 & 409 \\
\hline Age (years) & 19 & 43 & 92 & 13 & 14 & 39 & 93 & 17 & 9 & 35 & 91 & 13 \\
\hline Hdom (m) & 11.1 & 21.2 & 34.7 & 4.3 & 9.9 & 26.8 & 48.9 & 8.4 & 8.0 & 22.2 & 34.4 & 5.7 \\
\hline SI (m) & 13.1 & 25.4 & 32.7 & 2.3 & 19.3 & 36.0 & 44.7 & 4.3 & 20.8 & 28.4 & 37.5 & 2.6 \\
\hline Nha (N/ha) & 141 & 1226 & 6020 & 807 & 60 & 614 & 2250 & 463 & 98 & 729 & 3700 & 558 \\
\hline Gha $\left(\mathrm{m}^{2} / \mathrm{ha}\right)$ & 6.6 & 35.3 & 61.5 & 10.3 & 18.2 & 36.2 & 59.6 & 9.1 & 9.3 & 26.4 & 55.5 & 7.3 \\
\hline $\mathrm{Cg}(\mathrm{cm})$ & 26.3 & 67.3 & 150.3 & 20.9 & 39.1 & 106.4 & 265.8 & 47.6 & 28.4 & 80.1 & 170.8 & 26.1 \\
\hline Elevation (m) & 158 & 425 & 654 & 105 & 154 & 318 & 550 & 103 & 36 & 361 & 606 & 117 \\
\hline Slope $\left(^{\circ}\right)$ & 0 & 6 & 23 & 4.6 & 1 & 6 & 21 & 4.8 & 0 & 6 & 29 & 5.1 \\
\hline
\end{tabular}

Area $=$ sample plot area; Age $=$ total age of the stands since planting; Hdom $=$ top-height; SI $=$ site index; Nha $=$ number of trees per hectare; $\mathrm{Gha}=$ total basal area per hectare; $\mathrm{Cg}=$ quadratic mean girth at breast height

planting) was evaluated for every sampled stands by using the online tool "H50" v1.1 (Perin and De Thier 2014). The age, top-height and density range of the sampled stands are representative of what is mostly encountered in coniferous stands between the first thinning and the clearcutting.

\section{Method}

We decided to evaluate the tree-level distance-independent growth model of Deleuze et al. (2004) on our data because of its interesting formulation. This model has also already been tested in similar site conditions (Northeastern France) for Norway spruce and Douglas-fir stands subject to silvicultural management practices comparable to those encountered in Southern Belgium. It is a nonlinear hyperbolic model that describes annual tree basal area increment $\left(\mathrm{Ig}_{\mathrm{i}}\right)$ as a function of initial circumference $\left(\mathrm{C}_{\mathrm{i}}\right)$ :

$$
\begin{aligned}
I g_{i}= & 0.5 \times P \times\left(C_{i}-m \times A\right. \\
& +\sqrt{\left.\left(m \times A+C_{i}\right)^{2}-4 \times A \times C_{i}\right)}
\end{aligned}
$$

The three parameters $A, P$ and $m$ can all be expressed as functions of the stands characteristics, and each affects the model in very different ways (Fig. 2). The parameter $m$ has to be greater or equal to 1 and affects the general shape and the flexibility of the model. If $m$ is equal to 1 , the model is the segmented linear function of Dhôte (1991) where $I g_{i}$ is null from $C_{i}=0$ to the threshold $A$ and then increases with a slope equal to $P$. Greater values of $m$ give more flexibility to the model around the threshold $A$, essentially leading to a more gradual increase in tree basal area increment in relation to increasing circumference.

Deleuze et al. (2004) proposed the following formulation for parameters $A$ and $P$ :

$$
\begin{aligned}
A= & (A a+A b \times \text { Hdom }) \times(1+A c \times \exp (-\alpha \\
& \times \text { Gha } / \text { Hdom })) \\
P= & (P a+P b \times \text { dHdom }) \times(1+P c \times \exp (-\alpha \\
& \times \text { Gha } / \text { Hdom }))
\end{aligned}
$$

where Gha is the initial stand basal area per hectare in $\mathrm{m}^{2} /$ ha, Hdom is the initial stand top-height in meters and dHdom is the annual top-height increment during the growth interval in meter per year. As final top-height was not always measured in the recovered inventory data, the annual top-height increment is not consistently available. Thus, we will always use an estimated value for this variable, calculated with the corresponding top-height growth model fitted on stem analysis data by Perin et al. $(2013,2014)$, whose formulation and parameters values are presented in Eq. (4) and Table 2.

$$
\begin{aligned}
\text { Hdom }= & {\left[a \times\left(\operatorname{age}-\operatorname{age}_{M}\right)+\left(\frac{\operatorname{Hdom}_{M}}{\left[1-\exp \left(-\frac{\mathrm{age}_{M}}{c}\right)\right]^{r}}\right)\right] } \\
& \times\left[1-\exp \left(-\frac{\mathrm{age}}{c}\right)\right]^{r}
\end{aligned}
$$

where Hdom-age is the predicted height-age couple and Hdom $_{M^{-}}$age $_{M}$ is the measured height-age couple.

First, we tested the parameterized formulations of Deleuze et al. (2004) for Norway spruce and Douglas-fir directly on our data by comparing predicted and observed values to check its accuracy and applicability for Southern Belgium data. We then adapted the model to our data using the $\mathrm{nls}()$ nonlinear regression procedure in $\mathrm{R}(\mathrm{R}$ Core Team 2012). Several new formulations for parameters $A, P$ and $m$ were also tested in order to try to simplify the model while improving its performances on our dataset. 

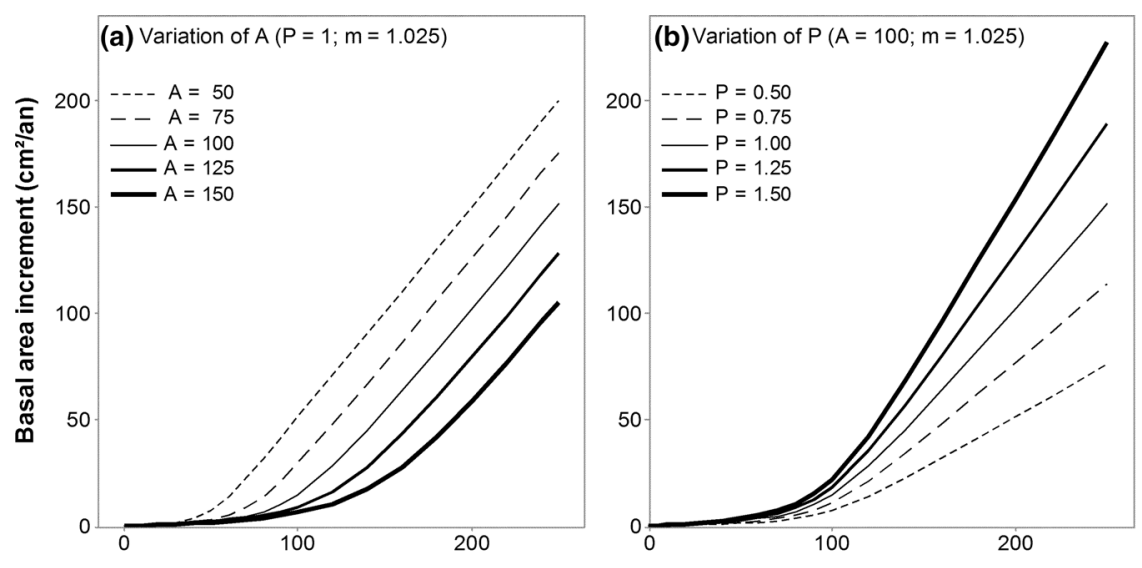

(a) Variation of $A(P=1 ; m=1.025)$

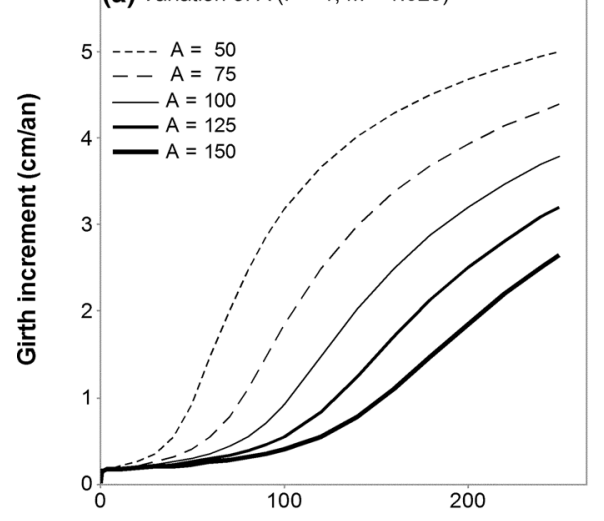

(c) Variation of $m(A=100 ; P=1)$
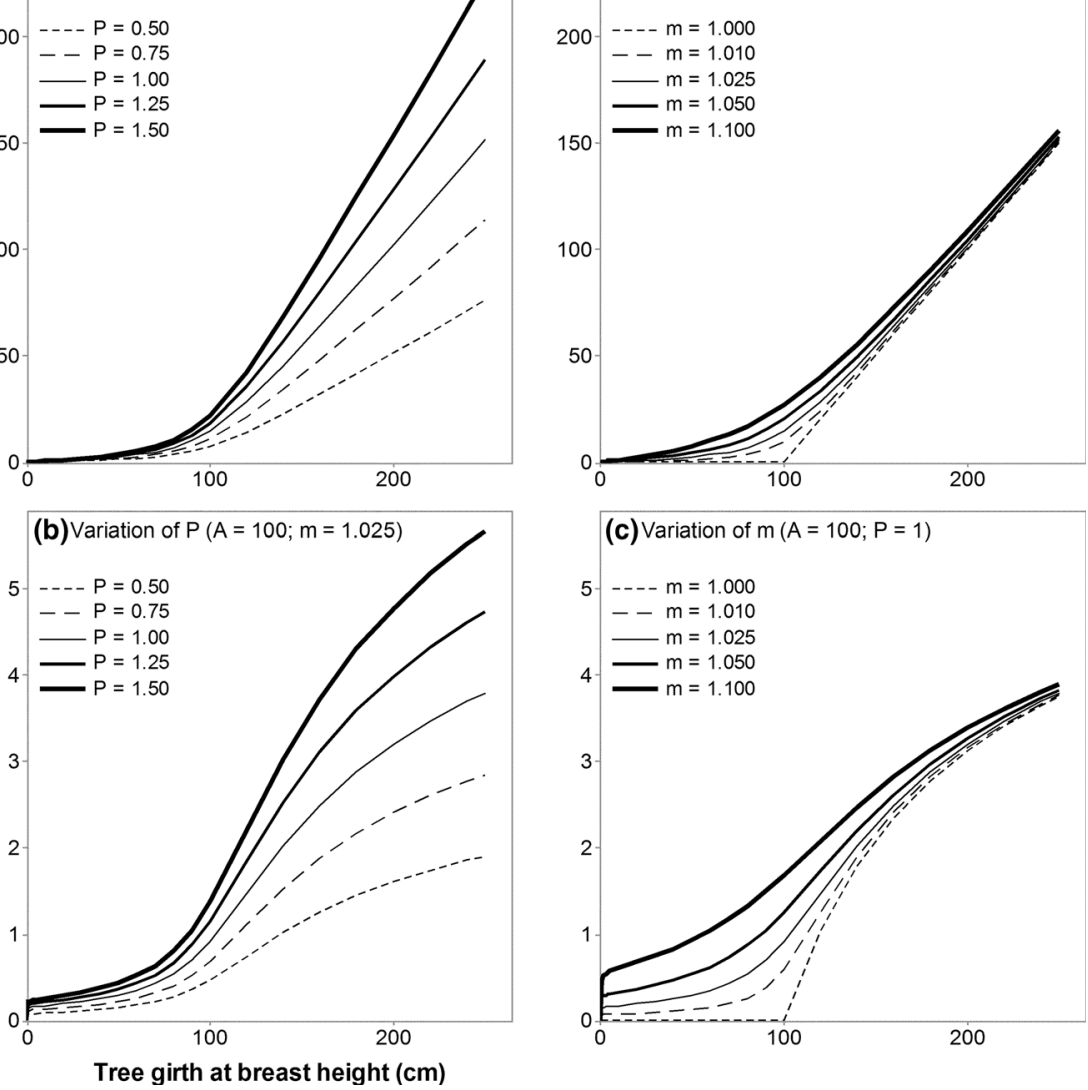

(c) Variation of $\mathrm{m}(\mathrm{A}=100 ; \mathrm{P}=1)$
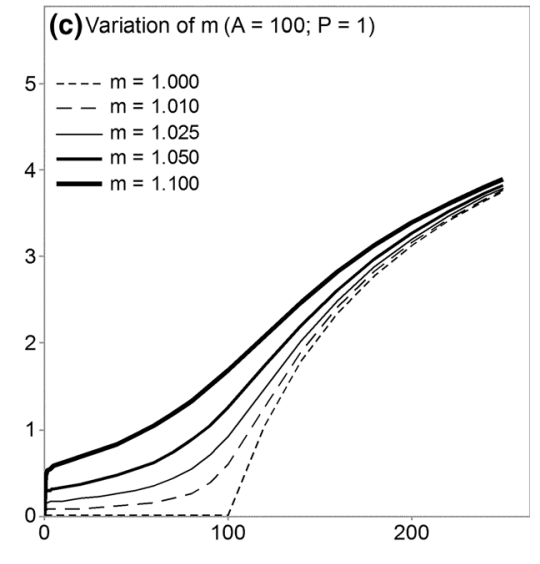

Fig. 2 Influence of the variation of one of the parameters $A, P$ or $m$ value on the tree growth model shape, other being constant: a variation of $A(50-150)$; $\mathbf{b}$ variation of $P(0.5-1.5)$; $\mathbf{c}$ variation of

Table 2 Corresponding parameters values of the top-height growth models fitted by Perin et al. (2014) for Southern Belgium Norway spruce, Douglas-fir and larch pure even-aged stands

\begin{tabular}{lllc}
\hline & $\begin{array}{l}\text { Norway } \\
\text { spruce (Picea } \\
\text { abies) }\end{array}$ & $\begin{array}{l}\text { Douglas-fir } \\
\text { (Pseudotsuga } \\
\text { menziesii) }\end{array}$ & $\begin{array}{l}\text { Larch } \\
\text { (Larix } \\
\text { kaempferi) }\end{array}$ \\
\hline$a$ & 0.1299 & 0.2418 & 0.1449 \\
$c$ & 22.3659 & 31.1379 & 14.9904 \\
$r$ & 2.0464 & 1.4668 & 1.6818 \\
\hline
\end{tabular}

The recovered data were quite heterogeneous as they were obtained from different sources that used different sampling and measurement methodology. In particular, the number of trees monitored in each sampled stands ranged from 10 to 300 . This needed to be addressed to avoid that some sampled stands outweigh too much the others during the parameterization of $A, P$ and $m$ formulations. We applied a simple weighting method to ensure that each sampled stands contribute to the fitting of the model in accordance with the length of the period it was monitored rather than the number of growth segments which were $m(1-1.1)$. Upper panels represent tree basal area increment $\left(\mathrm{cm}^{2} /\right.$ year); lower ones represent tree girth increment $(\mathrm{cm} /$ year)

measured: Each of the growth segment data was weighted by its length (in years) divided by the number of growth segments measured at the same time in the permanent sample plots (PSP). In this way, every sampled plot has a total weight equal to the total duration of its monitoring.

To take heteroscedasticity into account, Deleuze et al. (2004) weighted observations by $1 / C_{i}^{2}$, but this does not solve the issue for our dataset. We instead choose to fit the model on girth increment value $\left(I c_{i}\right)$ rather than tree basal area increment data $\left(I g_{i}\right.$ obtained from Eq. 1$)$ :

$I c_{i}=\left(C_{i}^{2}+4 \pi I g_{i}\right)^{0.5}-C_{i}$

We then validated the model by using a $K$-fold cross-validation procedure (Kohavi 1995). For each species, the sampled stands were sorted according to their size in the dataset (number of growth segments) and then spread in four independent and roughly equal-sized parts. The model was then fitted on three parts (training dataset) and then applied on the remaining part (validation dataset); this was done four times to ensure that every part was used as validation dataset. This way, the validation mean error and validation root-mean-square error can be used as the 
estimator of the predictive performance of the model when applied on an independent dataset.

All confidence intervals presented thereafter are calculated with a significance level of $\alpha=0.05$ ( $95 \%$ confidence level) unless stated otherwise.

\section{Results}

At first glance (Table 3), the original model and the fitted parameters values proposed by Deleuze et al. (2004) seemed to perform quite well on our data with an RMSE on the annual tree girth increment estimation of $0.60 \mathrm{~cm} /$ year for Norway spruce and $1.00 \mathrm{~cm} /$ year for Douglas-fir. Nevertheless, a bias was observed: On average, tree girth increment is overestimated by $0.18 \mathrm{~cm} /$ year for Norway spruce and by $0.23 \mathrm{~cm} /$ year for Douglas-fir. Moreover, we observed significant correlation between the residuals values and the girth of the measured trees (Fig. 3): Increments are generally rightly estimated for girth under $90 \mathrm{~cm}(\mathrm{dbh}$ under $30 \mathrm{~cm}$ ), but are noticeably overestimated for bigger trees.

We then parameterized the original model formulation on our dataset (Table 4), but were unable to meet the convergence criteria for Douglas-fir and Japanese larch (step-size factor was reduced below minFactor). This type of nonconvergence issue can often be explained by the use of an overparameterized model, and the correlation matrix of the parameters showed that the formulation for $A$ and $P$ was characterized by highly correlated parameters. Further test also highlighted that the suppression of either parameter $A a, A c$ or $P c$ greatly facilitated convergence while having little impact on the fitting performance of the models for all three species. Thus, it seemed relevant to seek for a simpler formulation of $A$ and $P$.

We determined that the model could be significantly simplified while keeping most of its fitting performances by transferring the expression of the stand density effect from the threshold and slope parameters $(A$ and $P$ ) to the shape parameter $(m)$. In this way, we found that the threshold parameter A could be expressed as a simple power function of dominant height and the slope parameter $P$ as a simple linear function of annual top-height growth.
Shape parameter $m$ was best expressed as an exponential function of top-height and total basal area that ensure that its value is always greater than 1 . The proposed formulations for parameters $A, P$ and $m$ are presented below:

$A=A a * \operatorname{Hdom}^{A b}$

$P=P a+P b * \mathrm{dHdom}$

$m=1+\exp (m a \times$ Hdom $-m b \times G h a)$

These formulations reduce the total number of parameters that need to be fitted to six instead of eight in the original formulation. Moreover, the formulations for the threshold and slope parameters $(A$ and $P)$ are simpler and no longer share the same explanatory variable.

The fitting of the new formulations easily met the convergence criteria for all three species and provided parameters estimates that were at least significant to the 0.05 level (Table 5). Compared to the original, the new formulation led to a small increase in the validation RMSE on annual tree girth increment estimation for Norway spruce $(+1.1 \%)$ and larch $(+2.1 \%)$ and to a minor decrease for Douglas-fir $(-0.5 \%)$. Further graphical analysis of the training and validation errors distributions according to each explanatory variable showed that the fitted models were unbiased and characterized by robust performance over the entire range of girth at breast height, age, topheight, site index and density represented in our dataset. As an example and for comparison with Fig. 3, the distribution of validation errors according to girth at breast height is represented in Fig. 4.

\section{Discussion}

The dataset representativity is always the most critical component in empirical growth modeling as it is essential that it covers all the conditions for which the model will have to be valid. We worked in collaboration with other researchers and the Nature and Forest Department of Wallonia (DNF) to collect measured data from all known observation networks, field experiments and forest inventories relevant to our study and representative of the wide diversity of conditions (sites, age, density, etc.)

Table 3 Evaluation on our dataset of the prediction errors of the models parameterized by Deleuze et al. (2004) for Norway spruce and Douglas-fir: root-mean-square error (RMSE) and mean error (ME) for

the annual tree girth increment estimation (cm/year) and the annual tree basal area increment estimation $\left(\mathrm{cm}^{2} /\right.$ year $)$

\begin{tabular}{|c|c|c|c|c|}
\hline & \multicolumn{2}{|c|}{ Norway spruce (Picea abies) } & \multicolumn{2}{|c|}{ Douglas-fir (Pseudotsuga menziesii) } \\
\hline & Ic $(\mathrm{cm} /$ year $)$ & $\operatorname{Ig}\left(\mathrm{cm}^{2} /\right.$ year $)$ & Ic (cm/year) & $\operatorname{Ig}\left(\mathrm{cm}^{2} /\right.$ year $)$ \\
\hline Prediction RMSE & 0.600 & 8.527 & 0.997 & 26.648 \\
\hline Prediction ME & 0.183 & 2.696 & 0.231 & 8.389 \\
\hline
\end{tabular}


Fig. 3 Distribution of the residuals (predicted-measured) on the annual girth increment estimation (in $\mathrm{cm} /$ years) obtained by applying the parameterized models of Deleuze et al. (2004) for Norway spruce and Douglas-fir on our dataset
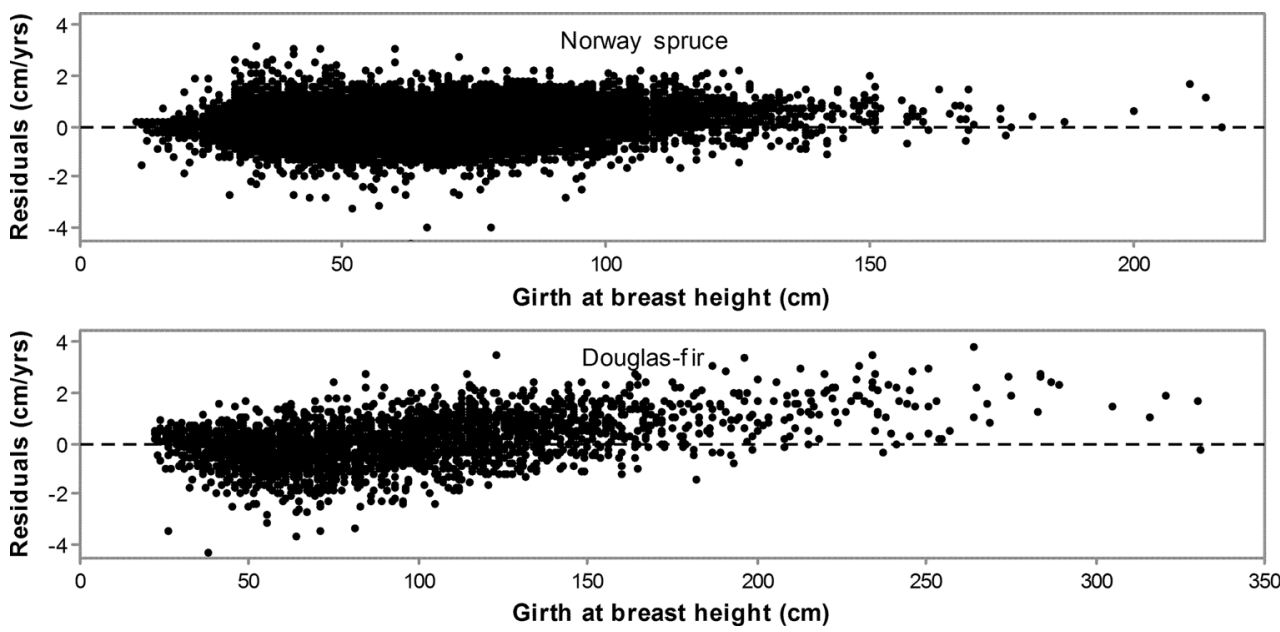

Table 4 Parameter values and fitting statistics of the original model formulation after parameterization on our data for Norway spruce, Douglas-fir and larch; the confidence interval $(1-\alpha=95 \%)$ is presented in italics next to each parameter value, and nonsignificant parameters values are followed by a hash symbol $\left({ }^{\#}\right)$; Akaike's
Information Criterion (AIC), training and cross-validation values of the root-mean-square error (RMSE), adjusted $R^{2}$ and mean error (ME) are also presented for the annual tree girth increment estimation $(\mathrm{cm} /$ year) and between bracket for the annual tree basal area increment estimation $\left(\mathrm{cm}^{2} /\right.$ year $)$

\begin{tabular}{llll}
\hline & Norway spruce (Picea abies) & Douglas-fir (Pseudotsuga menziesii) & Larch (Larix kaempferi) \\
\hline$A a$ & $-2.7140 \pm 0.8053$ & $-25.6905 \pm 36.2994^{\#}$ & $-41.3189 \pm 15.9502$ \\
$A b$ & $2.2520 \pm 0.0787$ & $5.5801 \pm 7.4928^{\#}$ & $8.0782 \pm 2.9599$ \\
$A c$ & $-0.8097 \pm 0.09$ & $-0.6923 \pm 0.3444$ & $-0.8739 \pm 0.0464$ \\
$P a$ & $0.1685 \pm 0.0094$ & $0.3124 \pm 0.1718$ & $0.0306 \pm 0.1203^{\#}$ \\
$P b$ & $0.5931 \pm 0.0298$ & $0.8482 \pm 0.4304$ & $0.0866 \pm 0.3434^{\#}$ \\
$P c$ & $1.0827 \pm 0.1938$ & $0.0521 \pm 0.7005^{\#}$ & $11.0773 \pm 47.6943^{\#}$ \\
$\alpha$ & $1.0228 \pm 0.0892$ & $0.2306 \pm 0.6124^{\#}$ & $0.2216 \pm 0.1103$ \\
$m$ & $1.0077 \pm 0.002$ & $1.0287 \pm 0.0121$ & $1.0361 \pm 0.0067$ \\
AIC & 4737673837 & 15278967 & 480512653 \\
Training RMSE & $0.530(7.141)$ & $0.757(16.417)$ & $0.608(8.918)$ \\
Adjusted $R^{2}$ & $0.620(0.691)$ & $0.505(0.726)$ & $0.630(0.677)$ \\
Validation RMSE & $0.539(7.250)$ & $0.775(16.810)$ & $0.614(8.997)$ \\
Validation ME & $-0.005(-0.117)$ & $0.017(0.089)$ & $0.000(-0.134)$
\end{tabular}

encountered in coniferous stands of Southern Belgium. The site index estimated in the sampled stands ranges from 13 to 32.5 for Norway spruce, $19.5-44.5$ for Douglas-fir and 21-37.5 for larch. These amplitudes are generally wider than those previously estimated by Perin et al. (2014) thanks to data recovered from some unusually low-productivity stands located in site conditions where these species are no longer planted (e.g., peatland and humid clay soils). We also recovered data from several silvicultural field experiments where a wide variety of planting spacing and thinning intensity were tested (e.g., Hébert et al. 2002; Pauwels et al. 2007). Thus, density and total basal area variability are also greater in our dataset than what is found in most Southern Belgium young and mature coniferous stands managed for timber production. The number of sampled stands, trees and measured growth segments in our dataset is consistent with what is typically used in this type of research (e.g., Monserud and Sterba 1996; Andreassen and Tomter 2003; Monty et al. 2007).

To fit on our dataset, we selected a model which had recently been proven adequate for Norway spruce and Douglas-fir in neighboring France (Deleuze et al. 2004) in sites and management conditions similar to those encountered in our study area, for example in the wooded plateau of the Ardennes which covers both part of Southern Belgium and Northern France. However, further test showed that the original parameterized models were not directly applicable in Southern Belgium as they lead to significantly overestimate Norway spruce and Douglas-fir growth when applied on our dataset (Fig. 3). It is possible that French 
Table 5 Parameters values and fitting statistics of the proposed six parameters model formulation after parameterization on our data for Norway spruce, Douglas-fir and larch; the confidence interval $(1-\alpha=95 \%)$ is presented in italics next to each parameter value; Akaike's Information Criterion (AIC), training and cross-validation values of the root-mean-square error (RMSE), adjusted $R^{2}$ and mean error (ME) are also presented for the annual tree girth increment estimation (cm/year) and for the annual tree basal area increment estimation $\left(\mathrm{cm}^{2} /\right.$ year, between parenthesis)

\begin{tabular}{llll}
\hline & Norway spruce (Picea abies) & Douglas-fir (Pseudotsuga menziesii) & Larch (Larix kaempferi) \\
\hline$A a$ & $3.9825 \pm 0.3010$ & $1.9987 \pm 0.4563$ & $4.7358 \pm 0.5610$ \\
$A b$ & $0.7802 \pm 0.0239$ & $1.0544 \pm 0.0619$ & $0.8241 \pm 0.0361$ \\
$P a$ & $0.2160 \pm 0.0089$ & $0.3725 \pm 0.0595$ & $0.3435 \pm 0.0182$ \\
$P b$ & $0.8014 \pm 0.0258$ & $0.8500 \pm 0.1103$ & $1.0514 \pm 0.0428$ \\
$m a$ & $0.1345 \pm 0.0107$ & $0.0415 \pm 0.0256$ & $0.0522 \pm 0.0081$ \\
$m b$ & $0.1853 \pm 0.0081$ & $0.1225 \pm 0.0230$ & $0.1328 \pm 0.0067$ \\
AIC & 4737674321 & 15278788 & 480504651 \\
Training RMSE & $0.537(7.173)$ & $0.758(16.334)$ & $0.622(9.065)$ \\
Adjusted $R^{2}$ & $0.607(0.685)$ & $0.499(0.729)$ & $0.612(0.666)$ \\
Validation RMSE & $0.545(7.284)$ & $0.771(16.619)$ & $0.627(9.125)$ \\
Validation ME & $-0.005(-0.141)$ & $0.009(-0.067)$ & $-0.001(-0.145)$
\end{tabular}

Fig. 4 Distribution of the validation residuals (predictedmeasured) on the annual girth increment estimation (in $\mathrm{cm} /$ years) obtained for Norway spruce, Douglas-fir and larch with our new formulation
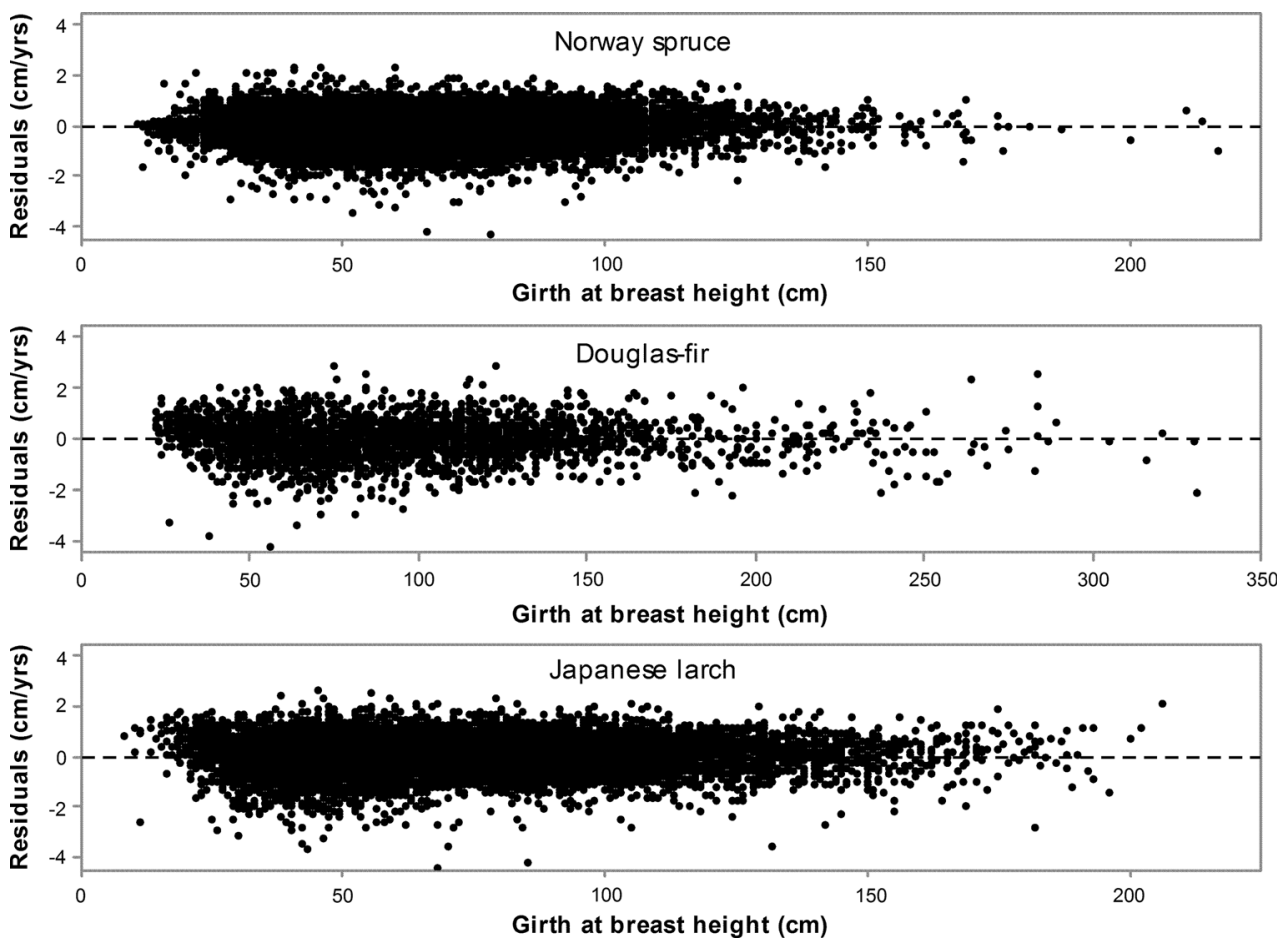

coniferous stands are generally more productive than their Belgian counterpart, but these divergences are more likely related to dataset and methodological differences. In particular, these models were fitted on data from experimental permanent plots of the AFOCEL's network which, according to a report of Gastine et al. (2003), were almost all installed in stands under the age of 45 years at the time of the study. The parameters estimates fitted by Deleuze et al. (2004) are thus probably less valid for coniferous stands over the age of 45 years which are quite common in
Southern Belgium (Alderweireld et al. 2015) and represent 45 and $20 \%$ of the sampled Norway spruce and Douglas-fir stands in our dataset.

Deleuze et al.'s general model formulation Eq. (1) is interesting as it allows to distribute the effect of the standlevel explanatory variables in three different parameters $(A$, $P$ and $m$ ) that influence the shape of the relation between individual girth and tree basal area increment in very contrasted way (Fig. 2), making this model very flexible while always ensuring a biologically plausible constrained 
form. In addition, individual girth being the only tree-level variable makes it really easy to represent and understand the influence of the explanatory variables on growth estimates, to evaluate the model robustness and finally to integrate it in a simulation software.

The parameter A determines the girth value below which tree growth is near zero and therefore represents a threshold below which trees could be considered as heavily suppressed. Our analysis showed that, consistent with the conclusion of Deleuze et al. (2004), this parameter was best expressed using variable related to the stand development stage (top-height, age, mean dbh, etc.), and the most suitable formulation appeared to be a power function of topheight. Combining height or top-height with tree girth value to identify suppressed trees can be linked to the tree height to diameter ratio (H/D) which is an already wellknown indicator of individual tree stability (e.g., Bruchert et al. 2000; Wonn and O'Hara 2001; Slodicak and Novak 2006) and of crown dimension (Dyer and Burkhardt 1987; Hasenauer and Monserud 1996) and has already been investigated as a potential competition index (Opio et al. 2000; Bachofen and Zingg 2001). Therefore, dividing tree girth by the corresponding A parameter, calculated value could provide an interesting indicator which would be inversely proportional to the past cumulative level of competition experienced by the tree and proportional to its present potential for utilizing growing space. In particular, estimates of this ratio close to (or less than) unity would probably indicate highly unstable trees with small crown ratio and low potential vigor that were heavily suppressed during a significant part of their lifetime.

The parameter $P$ has a simple multiplicative effect on the increment estimation that is independent of the dominance status of the trees. In accordance with Deleuze et al. (2004), we obtained excellent results by expressing this parameter as a simple linear function of the estimated top-height annual growth (dHdom). In our data, dHdom was always calculated using the corresponding top-height growth models (Perin et al. 2013, 2014) which are nonlinear function of age, site index and species. Thus, the parameter $P$ value is proportional to the estimated site index and increases to a maximum around the age of 10 years for larch and 20 years for Norway spruce and Douglas-fir, slowly decreasing thereafter. In practice, top-height annual growth also depends on annual climate variability, and thus, parameter $P$ would probably be the most suitable to integrate weather variables in its formulation.

The parameter $m$ determines the model flexibility around the threshold $A$, and its value has an important positive influence on the growth estimation of trees with a girth at breast height inferior or close to A, but almost none for bigger ones (Fig. 2). We identified $m$ as the ideal parameter to express the effect of density on growth. With the proposed formulation (Eq. 8), $m$ converges to 1 in denser stands, bringing the model closer to a segmented shape that ensures very low basal area growth estimation value for small suppressed trees which suffer from the intense competition for resources. This is consistent with the fact that dominant trees are less affected by competition than dominated ones (Schütz et al. 2015). The "competition effect" simulated by the parameter $m$ is also inversely proportional to the dominant height which indicates that a given total basal area value accounts for a higher level of competition in younger forests stands than in older ones.

Thereby, the stand density variable (Gha) was transferred into the formulation of the parameter $\mathrm{m}$, allowing us to greatly simplify the formulations of $A$ and $P$ so that they no longer share the same explanatory variables (Hdom and Gha). This allowed us to reduce the number of fitted parameters to six by species (instead of eight in the original formulation) and to significantly facilitate the fitting process convergence. Unlike the original formulation of Deleuze et al. (2004), this new formulation converged easily without requiring an initial estimation of the starting values for the model parameters (or a self-starting function): Using a starting value of 1 for each parameter proved to be perfectly appropriate on our dataset. We thus consider that the benefits of this new formulation more than offset the negligible loss of flexibility and precision.

The calculated adjusted $R^{2}$ shows that our parameterized models explain 61,50 and $61 \%$ of the annual girth increment variance and 68,73 and $67 \%$ of the annual basal area increment variance for Norway spruce, Douglas-fir and larch. Their level of performance (Table 5) seems relatively good (e.g., Monserud and Sterba 1996; Andreassen and Tomter 2003; Monty et al. 2007; Pauwels et al. 2007) and is probably close to the maximum that is possible to obtain with a distance-independent growth model that does not take climate annual variability into account. Thus, this model represents an interesting compromise between performance and utility as it only uses simple explanatory variables (age, Hdom, Gha, $\mathrm{Ci}$ ) that are usually collected in forest management inventories. This greatly facilitates the collection of an appropriate training dataset and allows a direct application of the parameterized model on actual forest inventory data in order to predict the growth of existing trees.

A theoretical application of these new growth models is presented in Fig. 5: Individual tree girth growth curves were built for each species in order to compare the development of dominant and suppressed trees in high- and low-density stands. We used values for the explanatory variables (Table 6) that are consistent with what can be encountered in Norway spruce, Douglas-fir and Japanese larch stands of average site index from Southern Belgium (Dagnelie et al. 1988; Rondeux et al. 1991; Pauwels et al. 

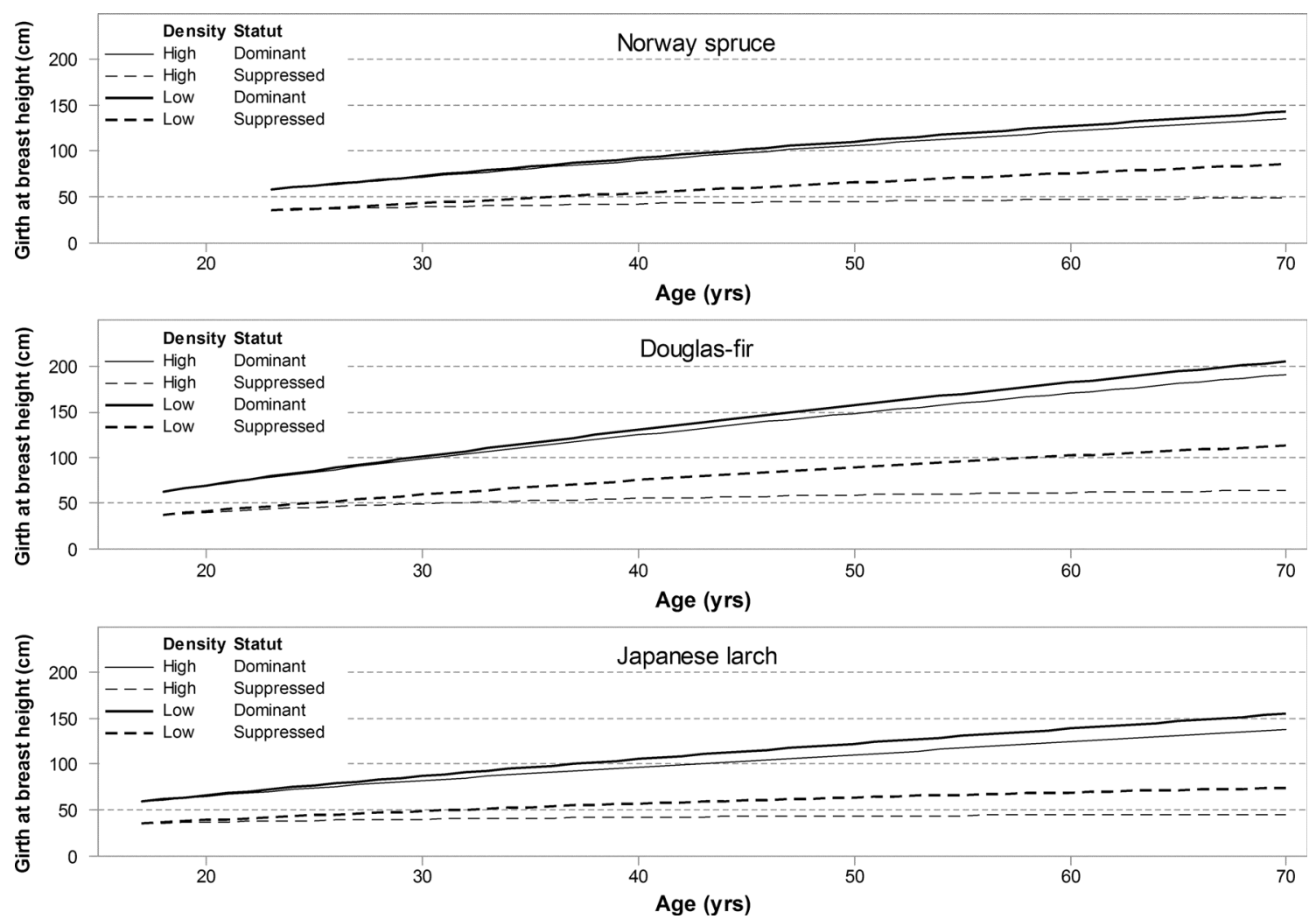

Fig. 5 Simulation with the new growth models of the evolution of the individual girth at breast height of dominant and suppressed trees of Norway spruce, Douglas-fir and Japanese larch in high- and low-density forest stands

Table 6 Parameters of the growth simulation presented in Fig. 5

\begin{tabular}{llll}
\hline & $\begin{array}{l}\text { Norway spruce } \\
\text { (Picea abies) }\end{array}$ & $\begin{array}{l}\text { Douglas-fir } \\
\text { (Pseudotsuga menziesii) }\end{array}$ & $\begin{array}{l}\text { Larch (Larix } \\
\text { kaempferi) }\end{array}$ \\
\hline Site index (top-height at age 50$)(\mathrm{m})$ & 27 & 36 & 27 \\
Initial age (14 m top-height) (year) & 23 & 18 & 17 \\
Initial tree girth (dominant) (cm) & 57.5 & 63 & 59.5 \\
Initial tree girth (Suppressed) (cm) & 34.5 & 37.8 & 35.7 \\
Initial stand density (high) $\left(\mathrm{m}^{2} / \mathrm{ha}\right)$ & 35 & 35 & 35 \\
Initial stand density (low) $\left(\mathrm{m}^{2} / \mathrm{ha}\right)$ & 25 & 25 & 25 \\
Annual evolution of stand density (m²/ha/year) & +0.25 & +0.25 & +0.25 \\
\hline
\end{tabular}

2007; Perin et al. 2014). The initial age was selected to match a dominant height of $14 \mathrm{~m}$ because it is consistent with the model validity range and usually corresponds to the first thinning stage in Southern Belgium coniferous stands (Alderweireld et al. 2015). The initial tree girth corresponds to a dominant tree juvenile growth of $2.5 \mathrm{~cm} /$ years for Norway spruce and $3.5 \mathrm{~cm} /$ years for Douglas-fir and Japanese larch and to $60 \%$ of those values for suppressed trees. In those examples, the stand total basal area (density) is initially fixed for low- and high-density stands at, respectively, 25 and $35 \mathrm{~m}^{2} / \mathrm{ha}$ and then increases by $0.25 \mathrm{~m}^{2} /$ ha each year.
These growth curves (Fig. 5) show that Douglas-fir is characterized by a substantially faster growth rate $(\approx+50 \%)$ than that of Norway spruce and Japanese larch which is consistent with the general knowledge about these species in Southern Belgium. It also highlights that density has a much greater effect on the growth rate of suppressed trees than that of dominant ones which is an important feature of this model that was already discussed before. The differences between the mean annual girth increment estimated in low- and high-density stands are equal to 8,10 and $18 \%$ for dominant trees compared to 73,65 and $74 \%$ for suppressed trees, respectively, for Norway spruce, 
Douglas-fir and larch. It also indicates that Japanese larch growth rate appears to be particularly sensitive to stand density variation as already highlighted by Pauwels et al. (2007) who recommended lower stand density for larch than for Norway spruce and Douglas-fir.

\section{Conclusion and perspectives}

The new girth growth parameterized models presented in this study allow for unbiased increment prediction over the entire range of girth at breast height, age, top-height, site index and density encountered in most monospecific Norway spruce, Douglas-fir and larch stands managed for timber production in Southern Belgium.

The model formulation is purposely ideal for forest simulation software as the explanatory variables needed are simple and usually collected in forest inventory: individual girth at breast height, total basal area, top-height and estimated annual top-height growth (calculated from the top-height and the age of the stand by using the corresponding site index model).

Future uses of these models concern the development of a forest simulation software to help optimize silvicultural management techniques and to predict medium- and longterm changes in softwood forest resources of Wallonia. We also intend to further test the generic capabilities of this model formulation with other species in regular stands, especially with hardwood.

Acknowledgements We appreciate the support provided by the Walloon Region-DGRNE through the "Accord-Cadre/Forest Research" project. We would like to address a special thanks to Ir. Hugues Lecomte from the Permanent Regional Forest Inventory of Wallonia (IPRFW) as well as to Dr. Quentin Ponette and Dr. José Genon of the Earth and Life Institute of the Catholic University of Louvain (UCL-ELIE) who provided some of the data used in this study.

\section{References}

Alderweireld M, Burnay F, Pitchugin M, Lecomte H (2015) Inventaire forestier wallon. Résultats 1994-2012. SPW, DGO3, DNF, Direction des Ressources forestières, jambes, $236 \mathrm{pp}$

Andreassen K, Tomter SM (2003) Basal area growth models for individual trees of Norway spruce, Scots pine, birch and other broadleaves in Norway. For Ecol Manage 180:11-24

Bachofen H, Zingg A (2001) Effectiveness of structure improvement thinning on stand structure in subalpine Norway spruce (Picea abies (L.) Karst.) stands. For Ecol Manage 145:137-149

Bossel H (1991) Modelling forest dynamics: moving from description to explanation. For Ecol Manage 42:129-142

Bruchert F, Becker G, Speck T (2000) The mechanics of Norway spruce (Picea abies (L.) Karst): mechanical properties of standing trees from different thinning regimes. For Ecol Manage $135: 45-62$
Burkhart H, Tomé M (2012) Modeling forest trees and stands. Springer, Berlin, p 458

Claessens H (2001) Faut-il bannir l'épicéa au nom de la gestion durable? Forêt Wallonne 49-50:36-44

Claessens H, Thibaut A, Rondeux J (1996) Le douglas en Belgique. Gembloux, Faculté universitaire des Sciences agronomiques, Centre de Recherche et de Promotion Forestières, Section Ecologie

Claessens H, Lecomte H, Pauwels D (2002) Le mélèze en Région wallonne: etat des lieux et stations potentielles. Forêt Wallonne 61:4-8

Contreras MA, Affleck D, Chung W (2011) Evaluating tree competition indices as predictors of basal area increment in western Montana forests. For Ecol Manage 262:1939-1949

Courbaud B, Goreaud F, Dreyfus Ph, Bonnet FR (2001) Evaluating thinning strategies using a tree distance dependent growth model: some examples based on the CAPSIS software "unevenaged spruce forests" module. For Ecol Manage 145:15-28

Crahay NI (1900) A propos de quelques résineux de l'Amérique du nord—Le sapin de douglas. Bull Soc Roy For Belg 8:340-351

Dagnelie P, Palm R, Rondeux J, Thill A (1988) Tables de production relatives à l'épicéa commun (Picea abies KARST.). Les presses agronomiques de Gembloux, Gembloux, p 122

Deleuze C, Pain O, Dhote J-F, Herve J-C (2004) A flexible radial increment model for individual trees in pure even-aged stands. Ann For Sci 61:327-335

Dhôte JF (1991) Modélisation de la croissance des peuplements réguliers de hêtre: dynamique des hiérarchies sociales et facteurs de production. Ann des Sci For 48:389-416

Dufour-Kowalski S, Courbaud B, Dreyfus P, Meredieu C, de Coligny F (2012) Capsis: an open software framework and community for forest growth modelling. Ann For Sci 69:221-233

Dyer ME, Burkhardt HE (1987) Compatible crown ratio and crown height models. Can J For Res 17:572-574

Gastine F, Bouvet A, Deleuze C, Monchaux P (2003) Le réseau des essais AFOCEL fête ses 40 ans! Revue Forestière Française $1: 47-56$

Hasenauer H, Monserud RA (1996) A crown ratio model for Austrian forests. For Ecol Manage 84:49-60

Hébert J, Herman M, Jourez B (2002) Sylviculture et qualité du bois de l'épicéa en région wallonne. ASBL Forêt Wallonne, Belgique, $\mathrm{p} 157$

Johnsen K, Samuelson L, Teskey R, McNulty S, Fox T (2001) Process models as tools in forestry research and management. For Sci 47:2-8

Kohavi R (1995) A study of cross-validation and bootstrap for accuracy estimation and model selection. Proc Fourteenth Int Joint Conf Artif Intell 2:1137-1143

Longchang L, Wenkang H, Guoqing W (1991) Study on the method of constructing variable-density yield table. J Northeast For Univ 2:95-99

Millard A (1949) Le mélèze du Japon. Bull Soc Roy For Belg $56: 377-382$

Monserud RA, Sterba H (1996) A basal area increment model for individual trees growing in even- and uneven-aged forest stands in Austria. For Ecol Manage 80:57-80

Monty A, Lejeune P, Rondeux J (2007) Individual distance-independent girth increment model for Douglas-fir in southern Belgium. Ecol Model 212:472-479

Opio C, Jacob N, Coopersmith D (2000) Height to diameter ratio as a competition index for young conifer plantations in northern British Columbia, Canada. For Ecol Manage 137:245-252

Pain O (1997) OASIS: le logiciel de sylviculture pratique, de la plantation à la coupe rase. Informations-forêt 552, $6 \mathrm{p}$ 
Pauwels D, Lejeune P, Rondeux J (2007) A decision support system to simulate and compare silvicultural scenarios for pure evenaged larch stands. Ann For Sci 64:345-353

Peng C (2000) Understanding the role of forest simulation models in sustainable forest management. Environ Impact Assess Rev 20:481-501

Perin J, De Thier O (2014) H50, estimateur d'indice de productivité. Online tool, version 1.1. http://hdl.handle.net/2268/167733. Accessed on 10 August 2015

Perin J, Hébert J, Brostaux Y, Lejeune P, Claessens H (2013) Modelling top-height growth and site index of Norway spruce. For Ecol Manage 298:62-70

Perin J, De Thier O, Claessens H, Lejeune P, Hébert J (2014) Nouvelles courbes de productivité harmonisées pour le douglas l'épicéa et les mélèzes en Wallonie. Forêt Wallonne 129:26-41

Porté A, Bartelink H (2002) Modelling mixed forest growth: a review for forest management. Ecol Model 150:141-188

Pretzsch H (2009) Forest dynamics, Growth and Yield. Springer, Berlin, p 664

Pretzsch H, Biber P, Ďurský J (2002) The single tree-based stand simulator SILVA: construction, application and evaluation. For Ecol Manage 162:3-21

Pretzsch H, Biber P, Schütze G, Bielak K (2014) Changes of forest stand dynamics in Europe. Facts from long-term observational plots and their relevance for forest ecology and management. For Ecol Manage 316:65-77

R Core Team (2012) R: a language and environment for statistical computing. R Foundation for Statistical Computing, Vienna, Austria. ISBN 3-900051-07-0. http://www.R-project.org/

Rondeux J, Laurent C, Thibaut A (1991) Construction d'une table de production pour le douglas (Pseudotsuga menziesii (Mirb.) Franco) en Belgique. Les cahiers forestiers de Gembloux 3, $23 \mathrm{pp}$
Schütz J-P, Ammann P, Zingg A (2015) Optimizing the yield of Douglas-fir with an appropriate thinning regime. Eur J Forest Res 134:469-480

Slodicak M, Novak J (2006) Silvicultural measures to increase the mechanical stability of pure secondary Norway spruce stands before conversion. For Ecol Manage 224:252-257

Thibaut A, Rondeux J, Claessens H (1995) Indices et courbes de fertilité pour les peuplements de douglas (Pseudotsuga menziesii (Mirb.) Franco) en Belgique. Les cahiers forestiers de Gembloux $16,11 \mathrm{pp}$

Twery M (2004) Modelling in forest management. In: Wainwright J, Mulligan M (eds) Environmental modelling: finding simplicity in complexity. Wiley-Blackwell, Hoboken, pp 291-301

Vacchiano G, Derose RJ, Shaw JD, Svoboda M, Motta R (2013) A density management diagram for Norway spruce in the temperate European montane region. Eur J Forest Res 132:535-549

Valbuena P, Del Peso C, Bravo F (2008) Stand density management diagrams for two mediterranean pine species in Eastern Spain. For Syst 17:97-104

Vanclay JK (1994) Modelling forest growth and yield: applications to mixed tropical forests. CAB International, Wallingford, pp 223-250

Weiskittel A, Hann D, Kershaw J, Vanclay J (2011) Forest growth and yield modeling. Wiley-Blackwell, Hoboken, p 415

Wimberly MC, Bare BB (1996) Distance-dependent and distanceindependent models of Douglas-fir and western hemlock basal area growth following silvicultural treatment. For Ecol Manage 89:1-11

Wonn HT, O'Hara KL (2001) Height:diameter ratios and stability relationships for four Northern Rocky Mountain tree species. West J Appl For 16:87-94 